\title{
First Paleoparasitological Study of an Embalming Rejects Jar Found in Saqqara, Egypt
}

\author{
Stéphanie Harter ${ }^{+}$, Matthieu Le Bailly, Francis Janot ${ }^{++}$, Françoise Bouchet \\ Laboratoire de Paléoparasitologie, EA 3308, associé CNRS ESA 8045, Université de Reims, U.F.R. de Pharmacie, 51, rue \\ Cognacq-Jay, 51096 Reims Cedex, France
}

For the first time, a jar of embalming rejects was studied in search for helminth parasite eggs. This kind of jar was used to put discarded material by Egyptian embalmers during mummification process. Ascaris lumbricoides and Tænia saginata eggs were found in the linen and strip fragment contents of the jar, dated of 2,715-2,656 years ago.

Keywords: paleoparasitology - ancient helminths - embalming - mummies - Egypt

In November 2001, within the limits of the excavation of the southwest sector of the Akhthetep's mastaba of Saqqara (Ziegler et al 1997), the archaeologists of the mission of the Louvre brought to light about twenty great jars in fragmentary terra-cotta mixed with natrum. These piriforme "rejection" vessels, characterized by two vertical handles, formed an important deposit of embalming rejects which can be dated from the 25 th dynasty (715656 BC) (Lecuyot 2000).

These vessels, most sealed with a cork in raw earth, were filled by the embalmer-priests with the remains of the mummification. These remains included bags of natrum, straw, linen, strips, papyrus marrows, fetid human humors such as decayed liquids and other materials mixed in small dishes, mugs and bottles that contained different ointments and oils. These were materials indispensable to the long and different mummification processes (Janot 2000) (Figs 1, 2). This deposit is a new testimony to the activity and the practice of the embalmerpriests. During this time, immortality is not reserved for an elite, but accessible to the whole Egyptian population. This is the first time that mummification remains have been studied within the framework of a paleoparasitological analysis.

The linen, the fragments of strips, natrum mixed in the straw, and the papyrus marrows were treated according to the same protocol originally used for the archaeological samples (Bouchet et al. 2001, 2002).

The samples were rehydrated for a week in $0.5 \%$ trisodic phosphate solution to which a $5 \%$ glycerin was added. The glycerin intensifies rehydration of lithified elements (Bouchet 1997). Every sample was then crushed in the mortar. The homogenized suspension was submitted to a ultrasound device for $5 \mathrm{~min}$ at $50^{\circ} \mathrm{C}$, on a frequency of $35 \mathrm{kHz}$, and the suspension strained through

${ }^{+}$Corresponding author. Fax: $+33-0-3-26-91.3547$. E-mail: stephanie.harter@univ-reims.fr

${ }^{++}$Ancien membre scientifique de l'I.F.A.O, 24, Via Garibaldi, 10121 Turin, Italie

Received 26 August 2002

Accepted 25 November 2002
315- $\mu \mathrm{m}, 160-\mu \mathrm{m}, 50-\mu \mathrm{m}$, and 25- $\mu \mathrm{m}$ meshes allowing a micrometric separation of helminth eggs. Only the last two screenings were examined. Parasite egg size falls between $30 \mu \mathrm{m}$ and $150 \mu \mathrm{m}$. Slides were prepared and observed under the light microscope.

Ascaris sp. and Taenia sp. eggs were identified in the samples taken from the contents of the embalming reject jars. However, the sample of papyrus marrow was negative for parasites.

The eggs of Ascaris sp., characterized by their mamillated eggshell have a size of $60 \times 40 \mu \mathrm{m}$ (Fig. 3), and so they can be ascribed to the species lumbricoides. This species is specific to mankind. Regarding the Taenia sp., the eggshells are very fragile, but embryophores surrounding the oncospheres were measured $35 \mu \mathrm{m}$ in diameter, with the characteristic radially striated membrane. They protect the cell of the hexacanthe embryo (Fig. 4). Two species of Taenia infect humans through consumption of poorly prepared meat: Taenia saginata from beef and Taenia solium from pork. According to their customs, Egyptians more frequently consumed beef rather than pork. Therefore, we think it is more likely that $T$. saginata was found in this study.

The two helminths, A. lumbricoides and T. saginata are localized in the intestine of the host that they parasitize. Their eggs are protected by a shell composed mainly of chitin, which allows them a long-lasting resistance to taphonomic processess (Wharton 1980, Bouchet et al. 1986).

Their presence in the jar confirms its use as "bowl of rejects" during the mummification. To our knowledge, no coproparasitological study has been performed on vases containing entrails put aside during the embalming process.

However, Ascaris was already found in histological preparations of intestinal tissues of the artificial mummy PUM II dated of Ptolemaïc time (Cockburn et al. 1975). Also, the presence of the Taenia sp. eggs was already recorded by electronic microscopy of histological sections of the intestine of the Egyptian mummy ROM, dated of 1198 years BC (Horne et al. 1977).

Our study widens the range of the material of research within the framework of the paleoparasitology. At present, analysis of coprolites, sediments, and organic remains is intensifying (Cockburn et al. 1975, Araújo et al. 1985, 
Reinhard et al. 1988, Ferreira et al. 1996, Bouchet 1997, Aspöck 2000). It is important to note that in the study of this jar the tissues used during the body mummification seem to have been contaminated by fecal material containing helminth eggs. For future studies we recommend

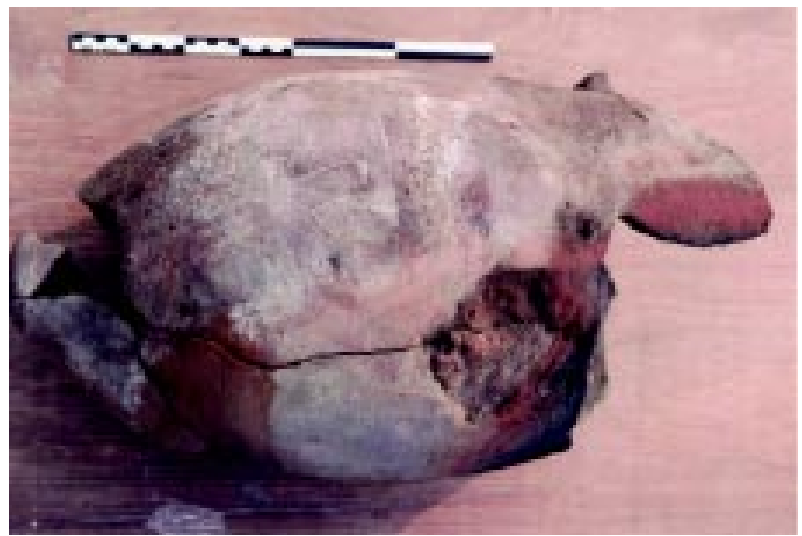

Fig. 1: embalming rejects jar, Department of Egyptian Antiquity, Louvre Museum, France.

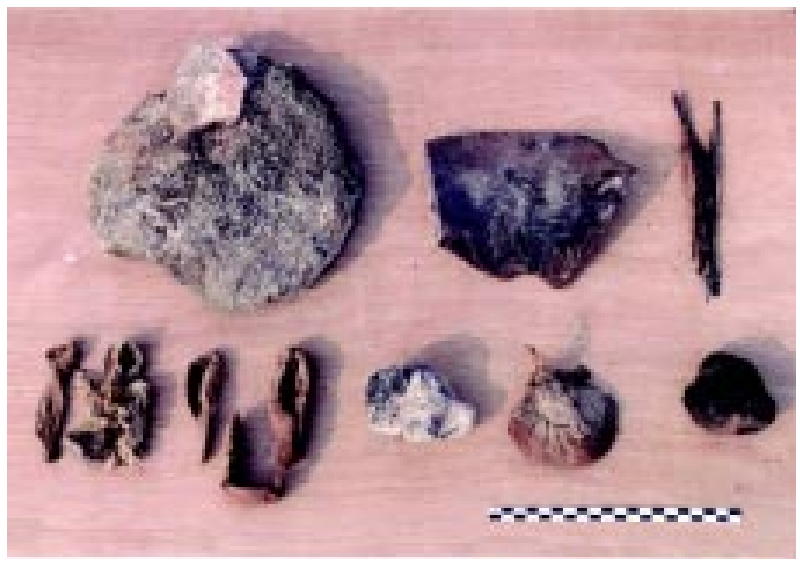

Fig. 2: embalming rejects jar contents, Department of Egyptian Antiquity, Louvre Museum, France.

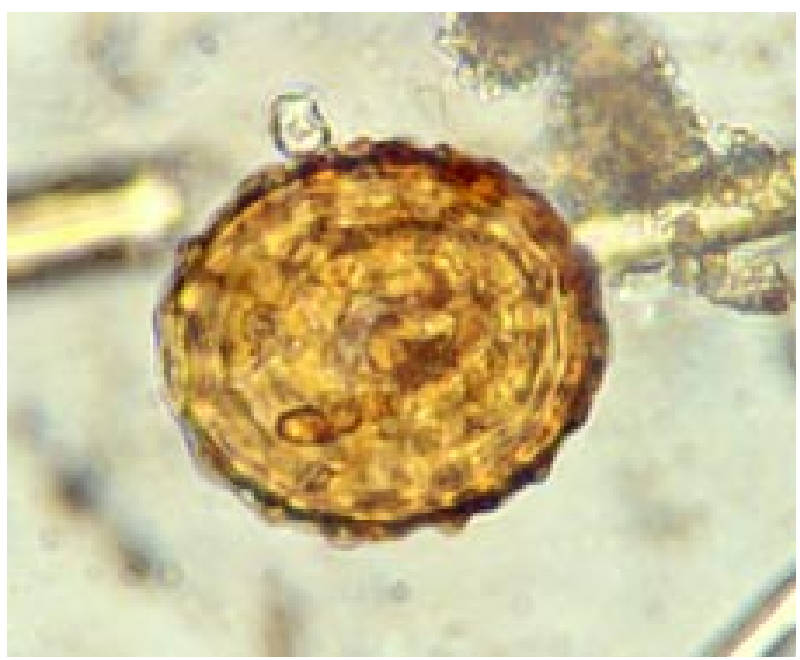

Fig. 3: Ascaris lumbricoides egg found in the contents of an Egyptian embalming rejects jar, Department of Egyptian Antiquity, Louvre Museum, France.

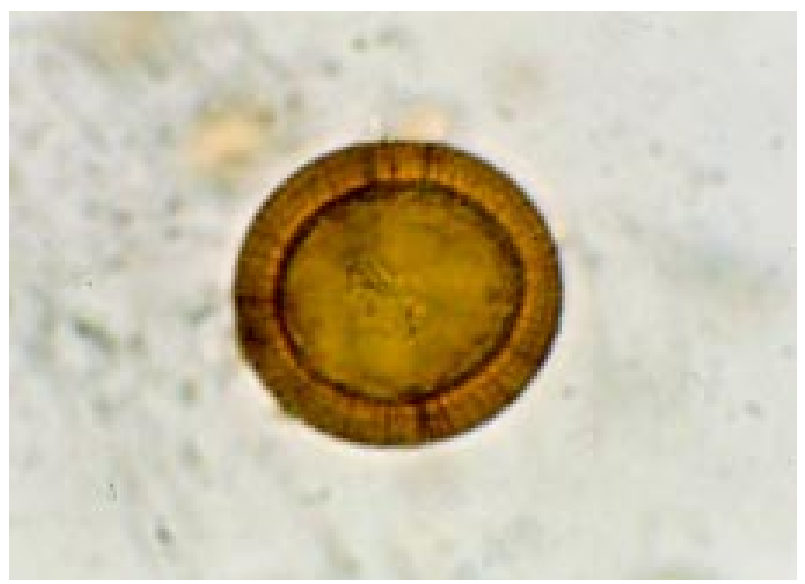

Fig. 4: Taenia sp. egg found in the contents of an Egyptian embalming rejects jar, Department of Egyptian Antiquity, Louvre Museum, France.

that researchers search for parasites in the shrouds of mummies, and even clothes or other wrapping tissues.

Helminths found in our study were recorded in the ancient Egyptian medical texts. The Ebers papyrus mentions the name of two worms, "pened" and "hefnat", which probably refers to roundworm and tapeworm. But it is impossible to know exactly to which species of helminth these words referred (Penso 1981). On the other hand, even if the Egyptians did not know the mechanisms of parasite infection, they were familiar with anthelminthic remedies (Bardinet 1995). It is unlikely that the priest contaminated the jar with his own infection. It is more likely that the eggs in the jar came from one or more individuals who had poor sanitation and food hygiene.

Regarding the samples of papyrus, the absence of parasites shows that the marrows were not contaminated with fecal material.

These observations confirm the possibility of obtaining paleopathological data from this type of sample. The obtained results open new perspectives in parasitology since the Ruffer's works (1910) and Cockburn's $(1975,1998)$ on Egyptian mummies.

A immediate collaboration with field archaeologists is necessary, even indispensable, to know the environmental context around the mummies. Henceforth, the study of these ancient periods should not limit itself in only describing the "splendors" of the past civilizations, but also take into account different kinds of material, such as the rubbish and garbage of vanished civilizations.

\section{ACKNOWLEDGEMENTS}

Thanks to Mrs Ch. Ziegler, General Conservative, charged with the Department of the Egyptian Antiquity in the Museum of the Louvre (France), which allowed this work.

\section{REFERENCES}

Araújo A, Ferreira LF, Confalonieri U, Nuñez L 1985. The finding of Enterobius vermicularis eggs in precolumbian human coprolites. Mem Inst Oswaldo Cruz 80: 141-143. 
Aspöck H 2000. Paläoparasitologie : Zeugen der Vergangenheit. Nova Acta Leopoldina 83: 159-181.

Bardinet Th 1995. Les Papyrus Médicaux de l'Egypte Pharaonique, Fayard, Paris, p. 258-262.

Bouchet F 1997. Intestinal capillariasis in neolithic inhabitants of Chalain (Jura, France). The Lancet 349: 256.

Bouchet F, Boulard Y, Baccam D, Leger N 1986. Ultrastructural studies of alterations induced by micro-waves in Toxocara canis eggs: prophylactic interest. Z Parasitenkend 72: 655764.

Bouchet F, Harter S, Paicheler JC, Araújo A, Ferreira LF 2002. First recovery of Schistosoma mansoni eggs from a latrine in Europe $\left(15^{\text {th }}-16^{\text {th }}\right) . J$ Parasitol 88: 404-405.

Bouchet F, West D, Corbett D, Lefevre C 2001. Palaeoparasitological analysis of a child Burial from Adak Island, Central Aleutian islands. CR Acad Sci Paris Sér III 324: 123127.

Cockburn A, Barraco RA, Reyman TA, Peck H 1975. Autopsy of an Egyptian mummy. Science 187: 1155-1160.

Cockburn A, Cockburn E, Reyman TA 1998. Mummies, Disease and Ancient Cultures, 2nd ed., Cambridge University Press, Cambridge, 402 pp.

Ferreira LF, Araújo AJG 1996. On hookworms and transpacific contact. Parasitol Today 12: 354.

Horne PD, Lewin PK 1977. Electron microscopy of mummi- fied tissue: autopsy of an Egyptian mummy. Can Med Ass $J$ 117: 472-473.

Janot F 2000. Les instruments d'embaumement de l'Egypte ancienne. $B d E$ 125: 91-118.

Lecuyot G 2000. La céramique du mastaba d'Akhethetep à Saqqara. Observations préliminaires. CEE 6: 239, figs 5 and 6.

Penso G 1981. La Conquête du Monde Invisible: Parasites et Microbes à Travers les Siècles, R Dacosta, Paris, 383 pp.

Reinhard KJ, Confalonieri UEC, Herrmann B, Ferreira LF, Araújo A 1988. Recovery of parasite remains from coprolites and latrines: aspects of palaeoparasitological technique. Homo (Gottingen) 37: 217-239.

Ruffer MA 1910. Note on the presence of Bilharzia haematobia in Egyptian mummies of the Twentieth Dynasty (12501000 BC). Br Med J 1:16.

Wharton DA 1980. Nematode egg-shells. Parasitology 81: 447 463.

Ziegler Ch 1997. La mission archéologique du Louvre à Saqqara. Dernières découvertes. CRAIBL Janvier-Mars: 169-177.

Ziegler Ch, Adam JP, Andreu G, Bridonneau C, Etienne M, Lecuyot G, Rozières MF (de) 1997. La mission archéologique du musée du Louvre à Saqqara. Résultats de quatre campagnes de fouilles de 1993 à 1996. BIFAO 97: 269-292. 
122 Parasites in Embalming Rejects - Stéphanie Harter et al. 